Kumawula, Vol. 3, No.2, Agustus 2020, Hal 280 - 288 DOI: https://doi.org/10.24198/kumawula.v3i2.27560

ISSN 2620-844X (online)

Tersedia online di http://jurnal.unpad.ac.id/kumawula/index

\title{
MENINGKATKAN LITERASI SISWA DESA SUKODONO, KECAMATAN DAMPIT, KABUPATEN MALANG MELALUI REVITALISASI PERPUSTAKAAN DESA
}

\author{
Bramantyo Tri Asmoro ${ }^{1 *}$, Devy Kumala Sari ${ }^{2}$ \\ ${ }^{1}$ Program Studi Ilmu Pemerintahan, Universitas Islam Raden Rahmat Malang \\ ${ }^{2}$ Program Studi Psikologi, Universitas Islam Raden Rahmat Malang \\ *Korespondensi: bramasmoro@uniramalang.ac.id
}

\begin{abstract}
ABSTRAK
Indeks minat baca di Indonesia masih sangat rendah, sehingga menyebabkan pemerintah melalui Kementerian Pendidikan dan Kebudayaan mengeluarkan Peraturan Menteri Pendidikan dan Kebudayaan Nomor 23 Tahun 2015, yang mewajibkan siswa membaca buku selama 15 menit sebelum pelajaran dimulai dengan tujuan untuk meningkatkan literasi siswa. Upaya peningkatan literasi siswa juga dilakukan oleh Pemerintah Desa Sukodono dengan membuat Perpustakaan Desa. Perpustakaan Desa dikelola oleh Karang Taruna, namun dalam perjalanannya Karang Taruna tidak maksimal dalam mengelola sehingga perpustakaan desa belum berfungsi sebagaimana mestinya. Kegiatan pengabdian kepada masyarakat ini dilakukan di Desa Sukodono, Kecamatan Dampit, Kabupaten Malang untuk meningkatkan minat baca siswa dengan melakukan revitalisasi perpustakaan desa, yaitu penambahan koleksi pustaka, melibatkan stakeholder dalam kegiatan dan promosi perpustakaan melalui lomba. Kegiatan pengabdian melibatkan Karang Taruna sebagai pengelola perpustakaan desa dan sekolah dengan tujuan untuk menciptakan keberlanjutan terhadap upaya peningkatan literasi siswa. Hasil dari kegiatan pengabdian yang dilakukan antara lain meningkatnya minat baca siswa sekolah dasar Desa Sukodono, bertambahnya koleksi pustaka dan meningkatnya pengetahuan dan kemampuan organisasi Karang Taruna dalam pengelolaan perpustakaan desa.
\end{abstract}

Kata kunci: literasi, perpustakaan desa, karang taruna

\begin{abstract}
The reading interest index of students in Indonesia is still very low, which caused Indonesian Government through the Ministry of Education and Culture issued Ministerial Regulation No. 23 of 2015, which requires students to read books for 15 minutes before the lessons begin in order to increase student literacy. The effort to increase student literacy was also carried out by the Sukodono Village Government by creating a Village Library. The Village Library is managed by the Youth Organization, but on its journey, the Youth Organization was not optimal in managed it, therefore the Village Library did not functioned properly. Community service activities were carried out in Sukodono Village, Dampit District, Malang Regency to increase students's interest in reading by revitalizing village libraries, namely adding library collections, involving stakeholders in library activities and promotion through singing and literacy contest. Community service activities involve the Youth Organization as the administrator of Village Library and schools at Sukodono Village, with the aim of creating sustainability towards efforts to increase student literacy. The results of the community service activities are the increase of reading interest of students, the increase of library collection and the increase knowledge and ability of the Youth Organization in managing Village Library.
\end{abstract}

Keywords: literacy, village library, youth organization 


\section{PENDAHULUAN}

Data statistik UNESCO pada tahun 2012 menyebutkan bahwa indeks minat baca di Indonesia baru mencapai 0,001. Indeks tersebut berarti hanya satu orang saja yang memiliki minat baca dari setiap 1000 orang di Indonesia (Nafisah, 2014). Kegiatan membaca tidak lagi menjadi prioritas ketika teknologi informasi memungkinkan seseorang untuk mendapatkan ilmu pengetahuan yang bisa diakses kapanpun, dimanapun, dan dalam situasi apapun. Riset yang dilakukan oleh Central Connecticut State University pada tahun 2016 dengan topik World's Most Literate Nations Ranked, menempatkan Indonesia pada peringkat 60 dari 61 negara dengan minat baca yang rendah (Kementerian Komunikasi dan Informatika, 2017). Perpustakaan Nasional RI pada tahun 2017 juga mengeluarkan data bahwa masyarakat Indonesia membaca buku hingga tamat sejumlah 5-9 buku saja tiap tahun. Budaya dengar dan budaya lisan dikalangan masyarakat Indonesia dianggap menjadi penyebab rendahnya minat dan budaya baca di Indonesia (Puspita dkk, 2018).

Arus informasi yang berkualitas dan dapat dipertanggungjawabkan menjadi kebutuhan yang sangat penting di era persaingan global yang semakin kompetitif. Fenomena rendahnya minat baca siswa tersebut disikapi oleh pemerintah melalui Kementerian Pendidikan dan Kebudayaan, dengan mengeluarkan Peraturan Menteri Pendidikan dan Kebudayaan (Permendikbud) Nomor 23 Tahun 2015. Permendikbud tersebut mengatur tentang tentang pembiasaan siswa dan guru untuk melakukan kegiatan membaca 15 menit sebelum pelajaran dimulai. Tujuannya adalah untuk meningkatkan budaya literasi siswa.

Salah satu kompetensi yang harus dimiliki oleh SDM yang handal adalah SDM yang literat (Kharizmi, 2015). Literat adalah kemampuan seseorang dalam membaca (literasi) dan menulis. Menurut Ana Nurhasah, literasi merupakan kemampuan membaca dan memahami teks, grafik, tabel, dan diagram dalam berbagai konteks (Pamungkas, 2017). Kemampuan literasi sangat diperlukan dengan tujuan siswa dapat lebih cerdas, kreatif dan inovatif, maka dari itu perlu dilakukan pembiasaan membaca sejak dini. Melalui membaca, seseorang dapat menggali informasi, mempelajari pengetahuan, memperkaya pengalaman, mengembangkan wawasan dan mempelajari segala sesuatu (Wahyuni, 2010). Salah satu upaya secara sederhana yang dapat dilakukan untuk meningkatkan minat baca siswa adalah dengan memaksimalkan kembali fungsi perpustakaan. Perpustakaan merupakan suatu satuan kerja organisasi, badan atau lembaga yang bertujuan untuk memberikan pelayanan kepada pemustaka dan bertujuan untuk meningkatkan kegemaran membaca masyarakat (Pamungkas, 
2017). Perpustakaan bisa berdiri sendiri dan bisa juga menjadi bagian dari organisasi yang lebih besar.

Perpustakaan sebagaimana yang tertuang dalam Pasal 3 Undang-Undang Republik Indonesia Nomor 43 Tahun 2007, berfungsi sebagai wahana pendidikan, penelitian, pelestarian, informasi dan rekreasi untuk meningkatkan kecerdasan dan keberdayaan bangsa. Agar keberadaan perpustakaan tetap diakui sebagai penyedia informasi bagi penggunanya, maka pengelola harus memperbaiki kualitas layanannya. Perbaikan kualitas layanan harus diiringi dengan promosi. Promosi bertujuan untuk memperkenalkan koleksi dan fasilitas perpustakaan kepada masyarakat. Salah satu cara yang dapat dilakukan untuk mempromosikan perpustakaan yaitu dengan cara mengadakan kegiatan di perpustakaan yang melibatkan staf perpustakaan dan pemustaka.

Pemerintah Desa Sukodono yang berada di Kecamatan Dampit, Kabupaten Malang, berusaha meningkatkan minat baca siswa sekolah dasar dengan cara membangun Perpusatakaan Desa Sukodono. Namun keberadaan Perpustakaan Desa Sukodono yang telah dirintis dan diresmikan pada bulan Maret 2019 masih belum banyak memberikan kontribusi bagi masyarakat, terutama siswa-siswa yang ada di Desa Sukodono. Berdasarkan hasil wawancara dengan kepala desa, tingkat buta huruf masyarakat di Desa Sukodono sangat rendah, namun kepala desa ingin memaksimalkan fungsi perpustakaan desa sebagai prasarana belajar tambahan bagi siswa sekolah dasar di Desa Sukodono. Beberapa faktor yang dapat diidentifikasi dalam pengelolaan perpustakaan desa yang tidak maksimal antara lain kurangnya pengetahuan dan manajemen Karang Taruna dalam tata kelola perpustakaan, koleksi buku dan fasilitas yang belum memadai dan promosi yang kurang sehingga tidak banyak dikunjungi siswa. Oleh karena itu, perlu dilakukan berbagai kegiatan untuk meningkatkan minat baca siswa antara lain dengan melakukan program promosi perpustakaan desa. Program kegiatan pengabdian ini dilakukan dengan melibatkan stakeholder terkait, seperti Karang Taruna sebagai pengelola perpustakaan desa dan sekolah-sekolah yang ada di Desa Sukodono sebagai pengguna perpustakaan.

\section{METODE}

Revitalisasi dapat diartikan sebagai kegiatan untuk menyadarkan, menyegarkan kembali, menghidupkan kembali, atau membangkitkan kembali (Echols et al, 1992). Menurut Kamus Besar Bahasa Indonesia, revitalisasi adalah proses, cara, perbuatan menghidupkan atau menggiatkan kembali. Berdasarkan definisi tersebur revitalisasi dalam kegiatan 
pengabdian ini adalah memaksimalkan peran Perpusatakaan Desa Sukodono sebagai pusat pembelajaran untuk mengingkatkan literasi siswa.

Metode yang digunakan dalam Pengabdian Kepada Masyarakat melalui KKN Tematik Unira Malang Kelompok 4 Tahun 2019 adalah Participatory Actions Research (PAR). Praktek Participatory Actions Research (PAR) dipercaya dapat menjadi alternatif pendekatan riset yang mampu mendorong terjadinya perubahan positif di masyarakat (Widianingsih, 2020). Oleh karenanya, pemahaman masyarakat terhadap perencanaan partisipatif merupakan sesuatu yang sangat diperlukan dalam upaya pelaksanaan partisipasi perencanaan pembangunan partisipatif (Solihah, 2020). Beberapa kegiatan yang dapat dilakukan dalam revitalisasi perpustakaan untuk meningkatkan peran sebagai agen perubahan antara lain, merancang berbagai program perpustakaan yang kreatif sehingga dapat menarik minat masyarakat, merubah image perpustakaan sebagai tempat yang membosankan dan tidak menarik, memperbaiki tampilan perpustakaan yang atraktif dan pemenuhan koleksi pustaka (Widuri, 2016). Berdasarkan beberapa rancangan tersebut, pelaksanaan kegiatan pengabdian kepada masyarakat dibagi menjadi tiga tahap, yaitu:

\section{Upaya Penambahan Bahan Pustaka}

Pada prinsipnya, pengadaan bahan pustaka di setiap perpustakaan merupakan sebuah kewajiban. Perpustakaan mempunyai tugas mengadakan, mengembangkan koleksi pustaka dan menghimpun informasi dalam segala macam bentuk, seperti buku, majalah, brosur, tukar menukar, maupun pembelian (Soeatminah, 1992). Menurut Sulistyo, pengadaan koleksi perpustakaan dapat dilakukan melalui usaha penambahan bahan-bahan bacaan yang belum dimiliki perpustakaan, atau bisa juga dengan menambah (menduplikasi) bahan-bahan pustaka yang jumlahnya masih kurang (Basuki, 1991). Upaya revitalisasi perpustakaan yang dilakukan selain menambah koleksi pustaka juga membuat pojok literasi. Pojok literasi ini berguna untuk mendekatkan buku kepada peserta didik. Buku bacaan mini yang memuat ilustrasi-ilustrasi menarik dan imajinatif yang dipamerkan di dinding-dinding perpustakaan berupa pamflet.

\section{Upaya Pelibatan Pengelolaan}

Gerakan literasi tidak bisa dilakukan secara sepihak, namun perlu juga didukung pihak lain untuk membudayakan literasi pada anak-anak pelajar yang ada di Desa Sukodono. Pihak yang dilibatkan dalam kegiatan gerakan literasi ini antara lain, organisasi kepemudaan yang diwakili oleh Karang Taruna dan tentunya melibatkan peran sekolah untuk mendukung program ini dalam membantu menghimbau peserta didik untuk turut berpartisipasi dalam 
kegiatan promosi perpustakaan serta membudayakan literasi di lingkungan sehari-hari. Sekolah Dasar di Desa Sukodono yang berpartisipasi dalam kegiatan literasi dan promosi perpustakaan ini meliputi SDN 1 Sukodono, SDN 2 Sukodono, MI AL-Ahzar, dengan jumlah keseluruhan 40 anak.

\section{Upaya Promosi}

Peserta didik tingkat Sekolah Dasar masih memiliki daya imajinasi dan kreatifitas yang murni. Ketertarikan anak-anak lebih bertumpu pada kegiatan-kegiatan yang bersifat kompetitif namun memacu kreatifitas, salah satunya dengan melakukan kegiatan lomba. Perpustakaan Desa Sukodono masih belum memiliki daya tarik bagi siswa untuk datang, hal ini disebabkan oleh kurangnya pengetahuan akan keberadaan perpustakaan desa yang dibangun untuk masyarakat desa, terutama siswa. Oleh karena itu, diperlukan upaya pengenalan / promosi perpustakaan desa pada masyarakat dengan mengadakan kegiatan lomba literasi pada anak-anak pelajar tingkat Sekolah Dasar di Desa Sukodono. Sasaran dalam lomba ini anak-anak pelajar tingkat Sekolah Dasar Desa Sukodono dengan tujuan menanamkan sejak dini kegiatan membaca dan membantu proses belajarnya di sekolah dengan bahan pustaka lain yang mampu menunjang bahan pustaka dari sekolah.

\section{HASIL DAN PEMBAHASAN}

\section{Isi Hasil dan Pembahasan}

\section{Upaya Penambahan Bahan Pustaka}

Koleksi buku yang tersedia di Perpustakaan Desa Sukodono berjumlah sekitar 100 eksemplar dan sebagian besar didominasi buku pengantar pembelajaran untuk tingkat Sekolah Menengah Atas dan buku-buku fiksi remaja. Kebutuhan bahan bacaan untuk siswa di tingkat Sekolah Dasar dan Sekolah Menengah Pertama belum terpenuhi, baik di sekolah maupun di perpustakaan desa. Perlu dilakukan sebuah upaya terobosan untuk menambah jumlah koleksi buku dengan sasaran yang bervariasi, seperti buku pengayaan untuk tingkat sekolah dasar, baik berupa buku-buku pelajaran, buku keterampilan, majalah anak dan lain-lain. Upaya dalam menambah koleksi buku dilakukan dengan menggalang donasi buku di beberapa tempat dan melalui sosial media dengan menggandeng Karang Taruna. Terdapat 100 eksemplar buku yang didapat dari kegiatan donasi, buku yang dikumpulkan meliputi majalah anak, buku dongeng, buku-buku pelajaran tingkat SD, SMP dan SMA, serta buku motivasi. Diharapkan ke depannya terdapat buku-buku non fiksi untuk masyarakat umum. Terutama 
buku-buku yang bertema budidaya kopi dan salak sebagai penunjang perekonomian masyarakat Desa Sukodono yang sebagian besar mengelola kopi dan salak.

\section{Upaya Pelibatan Pengelolaan}

Tugas pokok Karang Taruna diatur dalam Peraturan Menteri Sosial Nomor 77/HUK/2010 tentang Pedoman Dasar Karang Taruna Bab III Pasal 5 yang menyebutkan bahwa Karang Taruna bersama elemen pemerintah dan elemen masyarakat lainnya bersamasama menyelenggarakan pembinaan generasi muda dan kesejahteraan sosial. Desa Sukodono memiliki organisasi Karang Taruna yang beranggotakan hampir 50 pemuda dengan domisili asli Desa Sukodono. Organisasi Karang Taruna Desa Sukodono yang pada awalnya aktif kemudian cenderung pasif dalam berbagai kegiatan desa, termasuk pengelolaan perpusatakaan desa. Karang Taruna Desa Sukodono dilibatkan dalam gerakan literasi dengan tujuan Karang Taruna dapat lebih aktif mendukung keberlangsungan dan keberlanjutan Perpustakaan Desa Sukodono.

Kegiatan gerakan literasi diharapkan dapat meningkatkan semangat kerja anggota Karang Taruna. Secara jangka panjang, Karang Taruna diharapkan dapat melanjutkan gerakan literasi dengan cara memaksimalkan pelayanan perpustakaan desa, menambah koleksi bahan pustaka untuk siswa dan masyarakat umum. Selain itu, diharapkan Karang Taruna dapat berinovasi dalam membantu pelajar-pelajar tingkat SMP, SMA, dan masyarakat umum untuk meningkatkan kemampuan literasi pelajar Desa Sukodono baik melalui perpustakaan desa maupun melalui media lain.

\section{Upaya Promosi Perpustakaan}

Kegiatan promosi perpustakaan yang dilakukan untuk tingkatan Sekolah Dasar berupa kegiatan lomba literasi yang diselenggarakan di Perpustakaan Desa Sukodono (Gambar 1). Kegiatan lomba ini selain bersifat kompetitif namun juga eksploratif dan memacu kreatifitas anak-anak. Melalui lomba literasi ini, diharapkan siswa pelajar Desa Sukodono termotivasi menggemari sastra sejak dini dan memunculkan sastrawan-sastrawan baru di Indonesia. Jenis lomba yang diadakan yakni lomba membaca puisi dan lomba menyanyi lagu Kemerdekaan Indonesia. Karya puisi dan lagu yang telah ditentukan berupa syair-syair para sastrawan bertemakan perjuangan membela tanah air. 


\section{Gambar 1. Pelaksanaan Lomba Literasi}

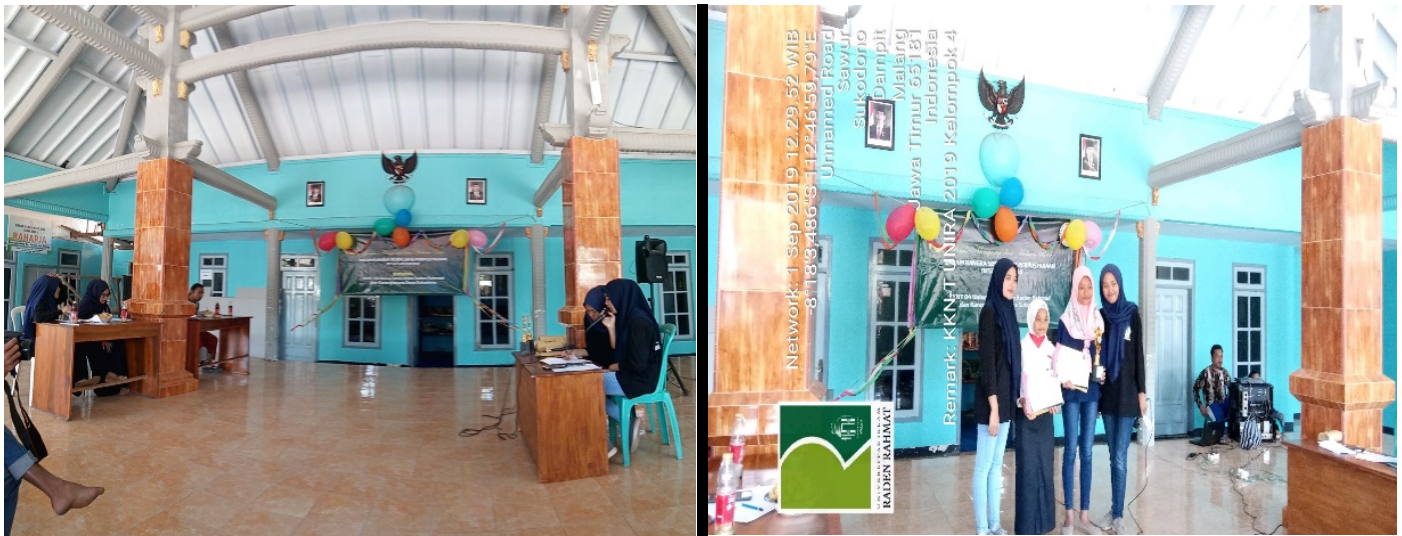

Kegiatan lomba yang disosialisasikan ke Sekolah Dasar di Desa Sukodono ini selain bertujuan untuk melakukan promosi Perpustakaan Desa Sukodono, juga untuk memantik kreatifitas dan bakat mereka di bidang sastra. Sebanyak 40 anak yang turut berpartisipasi dalam kegiatan ini terpilih tiga pemenang di masing-masing jenis lomba dengan kategori penilaian antara lain Lomba membaca puisi (Artikulasi, yaitu ketepatan dalam melafalkan kata-kata; Mimic, yaitu gerakan muka sebagai pernyataan perasaan hasil penjiwaan puisi; Intonasi, yaitu tekanan pada kata-kata dan kecepatan pengucapan kata dan Lomba menyanyi (Kerapian, penampilan ketika membawakan lagu; Ritme dan tempo, ketepatan suara sesuai dengan pola instrument lagu yang dimainkan; Intonasi, kontrol suara ketika menyanyikan lagu).

\section{SIMPULAN}

Program gerakan literasi dilakukan untuk meningkatkan minat baca anak pelajar di Desa Sukodono di tingkat Sekolah Dasar dengan memanfaatkan perpustakaan desa sebagai lahan baca anak-anak. Dalam melaksanakan program tersebut dilibatkan pula organisasi Karang Taruna dan sekolah guna adanya keberlanjutan program. Untuk mengajak dan meningkatkan ketertarikan anak-anak pelajar dilakukan beberapa upaya yakni khususnya dalam meningkatkan pelayanan perpustakaan desa seperti, menambah bahan pustaka, melakukan pengenalan/promosi perpustakaan melalui kegiatan lomba literasi di area perpustakaan desa, serta dalam kegiatan ini juga dilibatkan Karang Taruna dan sekolahsekolah dasar di Desa Sukodono guna mendukung keberlangsungan dan keberlanjutan program. Hasil kegiatan pengabdian yang dilakukan antara lain bertambahnya pengetahuan dan kemampuan organisasi karang taruna dalam pengelolaan perpusatakan desa, 
bertambahnya koleksi pustaka untuk siswa dasar dan menengah serta meningkatnya budaya literasi untuk siswa sekolah dasar. Gerakan literasi tidak dapat dibangun secara instan dan perlu dilakukan secara kontinyu, sehingga diperlukan adanya campur tangan atau dukungan dari Pemerintah Desa Sukodono, melalui organisasi desa yakni Karang Taruna serta dari pihak sekolah.

\section{DAFTAR PUSTAKA}

Basuki, S. (1991). Pengantar Ilmu Perpustakaan. Jakarta: PT Gramedia Pustaka Utama.

Echols, J.M., and Shadily, H. (1992). Kamus Inggris - Indonesia. Jakarta: Gramedia Pustaka Utama

Kementerian Komunikasi dan Informatika. (2017). TEKNOLOGI Masyarakat Indonesia: $\begin{array}{llll}\text { Malas } & \text { Baca } & \text { Tapi } & \text { Cerewet }\end{array}$ Medsos. (https://www.kominfo.go.id/content/detail/10862/teknologi-masyarakat-indonesiamalas-baca-tapi-cerewet-di-medsos/0/sorotan_media, diakses 19 September 2019)

Kharizmi, M. 2015. Kesulitan Siswa Dasar Dalam Meningkatkan Kemampuan Literasi. JUPENDAS, 2 (2), September 2015, 11-21.

Nafisah, A. (2014). Arti Penting Perpustakaan bagi Upaya Peningkatan Minat Baca Masyarakat. Jurnal Perpustakaan Libraria, 2 (2), 70-81.

Pamungkas, A. S. (2017). Pengembangan Bahan Ajar Berbasis Literasi pada Materi Bilangan bagi Mahasiswa Calon Guru SD. Jurnal Pendidikan Sekolah Dasar, 3 (2), 228-240.

Peraturan Menteri Pendidikan dan Kebudayaan Nomor 23 Tahun 2015

Puspita, G.A., dan Irwansyah. (2018). Pergeseran Budaya Baca dan Perkembangan Industri Penerbitan Buku di Indonesia: Studi Kasus Pembaca E-Book Melalui Aplikasi iPusnas. BIBLIOTIKA: Jurnal Kajian Perpustakaan dan Informasi, 2 (1), 13-20.

Soeatminah. (1992). Perpustakaan, Kepustakaan dan Pustakawan. Yogyakarta: Karnisius

Solihah, R. 2020. Perencanaan Partisipatif Dalam Program Citarum Harum Di Desa Kutamandiri Kecamatan Tanjungsari Kabupaten Sumedang. Kumawula: Jurnal Pengabdian Kepada Masyarakat. 3 (1), April 2020, Hal 29-47. DOI:http://10.24198/kumawula.31i1.24860 
Undang-Undang Republik Indonesia Nomor 43 Tahun 2007

Wahyuni, S. 2010. Menumbuhkembangkan Minat Baca Menuju Masyarakat Literat. Jurnal DIKSI, 17 (1), Januari 2010, 179-189.

Widianingsih, I. 2020. Strategi Peningkatan Penyadaran Isu Lingkungan Bagi Siswa Sekolah Dasar Melalui Permainan Ular Tangga: Kontribusi Unpad Untuk Program Citarum Harum. Kumawula: Jurnal Pengabdian Kepada Masyarakat. 3 (1), April 2020, Hal 116-128. DOI:http://10.24198/kumawula.v3i1.24598

Widuri, N.R. (2016). Revitalisasi Peran Perpustakaan Umum bagi Masyarakat. Jurnal Pustaka Ilmiah. 2 (1), 109-115. 